\title{
Assessment of Position and Symmetry of the Chin Following Reconstruction of Mandible with Autogenous Iliac Bone Grafts and Non Pre-Shaped Titanium Reconstruction Plates: A Comparative Pilot Study of Visual Perception and Computer Analyzed 2D Photo Image
}

\author{
Babatunde O Akinbami* and Udeabor SE
}

Department of Oral and Maxillofacial Surgery, University of Port Harcourt Teaching Hospital, Rivers State, Nigeria

*Corresponding author: Babatunde O Akinbami, BDS (Lagos), Department of Oral and Maxillofacial Surgery, University of Port Harcourt Teaching Hospital, Rivers State, Nigeria, Tel: +08068556516; E-mail: akinbamzy3@yahoo.com

Rec Date: Oct 17, 2014; Acc Date: Nov 14, 2014; Pub Date: Nov 22, 2014

Copyright: ( $) 2014$ Akinbami BO et al., This is an open-access article distributed under the terms of the Creative Commons Attribution License, which permits unrestricted use, distribution, and reproduction in any medium, provided the original author and source are credited.

\begin{abstract}
To restore acceptable facial profile after avulsion or ablation, the missing portions of the mandible must be adequately reconstructed. The purpose of this study was to compare the perception of individuals on mandibular chin dimensions and computer analyzed images following reconstruction of the mandible in a Nigerian tertiary health center.
\end{abstract}

Method: Ten patients with tumors involving the anterior part of the mandible were included. There were 2 groups of assessors. Patients were seated on the dental chair with back rest reclined at 90 degrees. Position of the chin was assessed from the side and symmetry was assessed from the front. Images were transported to computer for analysis. The coronal images were segmented into two halves with a vertical midline. On both sides to the midline, a vertical line was drawn. For the sagittal images, a vertical line was drawn to pass through the nasal sill.

Result: From the objective analysis, 5 of the patients had their chin in normal or very close to normal positions, 4 had mild retrusions $(\leq 2 \mathrm{~mm})$ and 1 had moderate retrusion $(\geq 2)$. When evaluations were compared, more clinicians graded more accurately than para-clinicians in all the patients. Objectively, 8 patients had less than $2 \mathrm{~mm}$, 1 patient had $2.5 \mathrm{~mm}$ and one had $5.5 \mathrm{~mm}$ (severe asymmetry). When evaluations were compared, 5 or more assessors in both groups graded correctly in 6 patients.

Conclusion: Chin positions were normal based on objective evaluation in half of the cases, while symmetry was very close to normal in only one case.

Keywords: Mandibular chin; Reconstruction; Position; Symmetry; Comparison

\section{Introduction}

The position of the chin of the mandible is one of the characteristics that reflect facial attractiveness of humans in most populations [1,2]. In other words, when the chin is moderately or excessively protruded or retruded, it tends to create an altered aesthetics which may be real or perceived but level of perception also varies in individuals [3]. Tumors of the mandible are one of the numerous diseases that affect or extend to the chin of this lower jaw bone causing swelling, displacement and asymmetry of the face [4]. Solid/multicystic Ameloblastomas affecting the mandible is the commonest odontogenic benign tumor seen in our patients but they present late to the hospital causing gross extension of the tumor [5].

Few articles have been written on the influence of level of perception of chin prominence on facial attractiveness but this has been done on computer simulated facial silhouettes [5,6]. It is therefore necessary to relate some of the deductions of these virtual images to our experience on actual reconstructive surgeries of the mandible. It is actually difficult to reproduce the accurate morphology of the grossly destroyed mandible however; improvement on such reconstructive procedures was the reason for this study. The purpose of this study was to compare the perception of individuals on the position and symmetry of both sides of the mandibular chin with findings of computer analyzed images following reconstruction of the mandible. It is expected that there will be differences in the visual judgments of individuals on the normal position and symmetry of the chin, especially amongst paraclinicians. However such differences may not be very significant when compared with clinical $2 \mathrm{D}$ photo evaluations.

\section{Patients and Method}

The study was a non randomized observational clinical study conducted in the Department of Oral and Maxillofacial surgery, University of Port Harcourt Teaching Hospital, Port Harcourt, Rivers State, Nigeria. Ethical approval was provided by the hospital's ethics and research committee. Ten (5 males and 5 females) patients operated between May 2010 and December, 2013; age range 10-49 years with mean (SD), 26.2 (14.7) years were evaluated. The patients gave their informed consent for surgery to be performed and inclusion into the study. Included in the study were patients with benign odontogenic tumor (ameloblastoma) that extended to the anterior part 
Citation: Akinbami BO, Udeabor SE (2014) Assessment of Position and Symmetry of the Chin Following Reconstruction of Mandible with Autogenous lliac Bone Grafts and Non Pre-Shaped Titanium Reconstruction Plates: A Comparative Pilot Study of Visual Perception and Computer Analyzed 2D Photo Image. Dentistry 4: 264. doi:10.4172/2161-1122.1000264

Page 2 of 5

of the mandible with chin involvement. Excluded from the study were those with lesions confined to the posterior part of the mandible from the distal aspect of the canine to the condyle, cases in which marginal resection was done and cases in which reconstruction plate was not used.

Surgical planning were done on all patients to specify points of resection, type and dimensions of reconstruction plates as well as the holes to use and points to drill on the residual bone segments [4]. All had resection of mandible due to ameloblastoma (Figure 1) and reconstruction with non vascularized iliac bone grafts of a range size of $6-10 \mathrm{~cm} \times 2.5 \mathrm{~cm}$ and, reconstruction plates (Synthes, Switzerland, $10 / 12 \mathrm{~mm}$ long screws or KLS Martins, Germany, 9/11 mm long screws; $2.0 / 2.4 \mathrm{~mm}$, angled 6holes/straight $20-24$ holes or straight plates 20-24holes). We utilized upper jaw/teeth relationships, as well as holes on the plate to determine the length, position of bend and contour of the plate. All operations were performed by the two authors (B.O \& S.E).

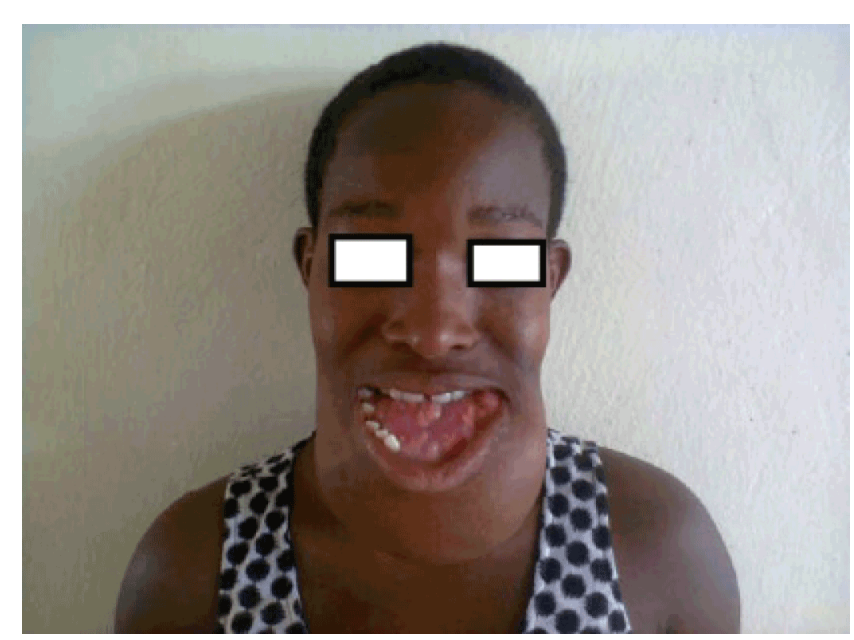

Figure 1: Showing preoperative photograph of fifth female patient with Solid/Multicystic Ameloblastoma of the Mandible

A total of 22 assessors were recruited and divided into 2 groups. Each group had 11 assessors. The clinician group had two consultant oral and maxillofacial surgeons, one consultant restorative dentist, eight resident doctors and one house officer. The para-clinician group had eight Dental Surgery assistants and 3 ward nurses. Pre-morbid photographs of the patients were requested for comparisons but were not available. Assessments were done between 6-18 months follow-up. They were given orientation on how to do a subjective visual assessment of each patient. Same individuals were used as assessors for all the patients. The assessment involved sitting patients on the dental chair and head was placed in neutral position. With the assessor standing in front of the patient, with a fixed gaze on the midline of the face, the two sides of the chin was compared for equality of symmetry. Protrusion or retrusion of the chin was assessed with assessor standing either on the left or right side. Each patient was also given mirror for self assessment and for the children; the assessment was made by the parent.

Objective assessments were done by capturing the coronal and sagittal postoperative photographic views of patients with same camera of 8 Megapixels and by one photographer. Same distances and positions were maintained for the purpose of standardization; these images were transported to HP laptop computer for analyses with Corel-draw software version 16.

For symmetry, the coronal image of the face was segmented into two halves with a vertical line passing through the region of the symphysis. Two other vertical lines were also drawn, each passing through the regions of the parasymphyses [5]. Distances between the midline and these sidelines were measured and the differences documented (Figure 2).

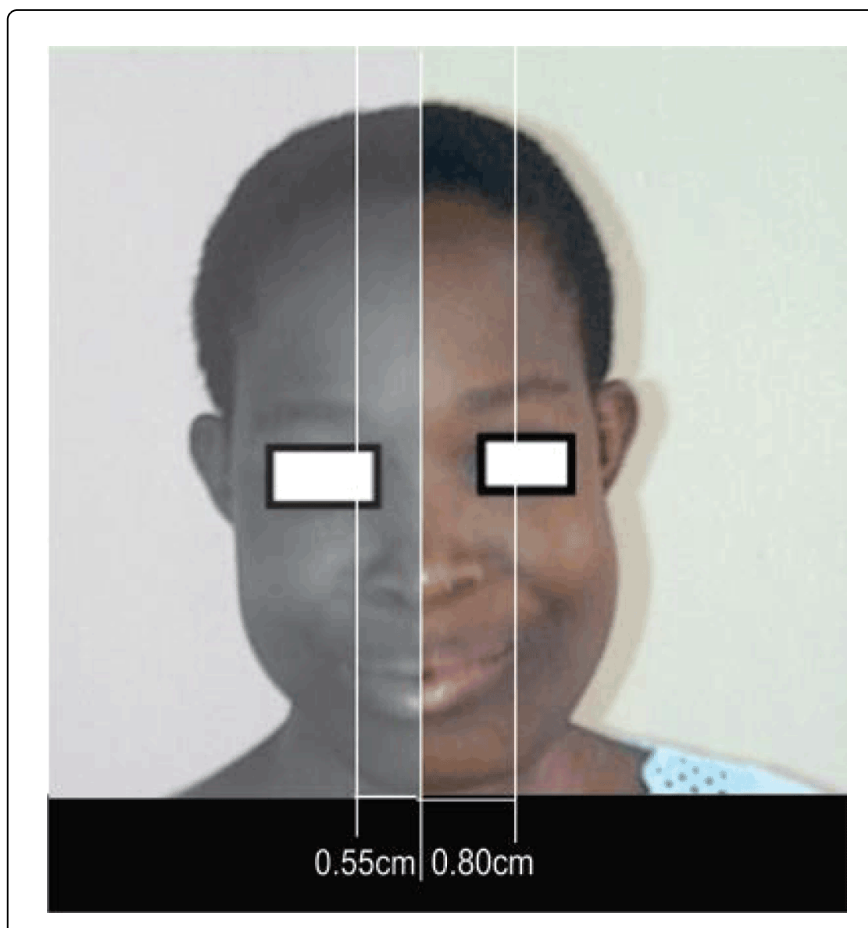

Figure 2: Showing front view of post-operative photograph of same female patient

For protrusion/retrusion, the sagittal image was used; a vertical line was drawn to pass through the nasal sill (Figure 3). When this line touches the anterior surface of soft tissue over the chin, the chin position is normal. If this first vertical line does not come in close contact (Figure 4), another vertical line was drawn either anterior or posterior to the first line in order to determine the extent of protrusion or retrusion [5].

Both subjective and objective assessments of the position and symmetry of the chin were graded into normal, mild (difference of 2 $\mathrm{mm})$, moderate $(4 \mathrm{~mm})$ and severe $(6 \mathrm{~mm})$.

Data obtained was analyzed with SPSS version 16, SPSS Inc, Chicago, Illinois. Intra and intergroup comparisons were done for subjective assessments of the 2 groups with one way ANOVA, F and P values were documented. Subjective assessments of each group were compared with the objective $2 \mathrm{D}$ photo evaluations using Chi square and $\mathrm{p} \leq 0.05$ were considered significant. 
Citation: Akinbami BO, Udeabor SE (2014) Assessment of Position and Symmetry of the Chin Following Reconstruction of Mandible with Autogenous lliac Bone Grafts and Non Pre-Shaped Titanium Reconstruction Plates: A Comparative Pilot Study of Visual Perception and Computer Analyzed 2D Photo Image. Dentistry 4: 264. doi:10.4172/2161-1122.1000264

Page 3 of 5

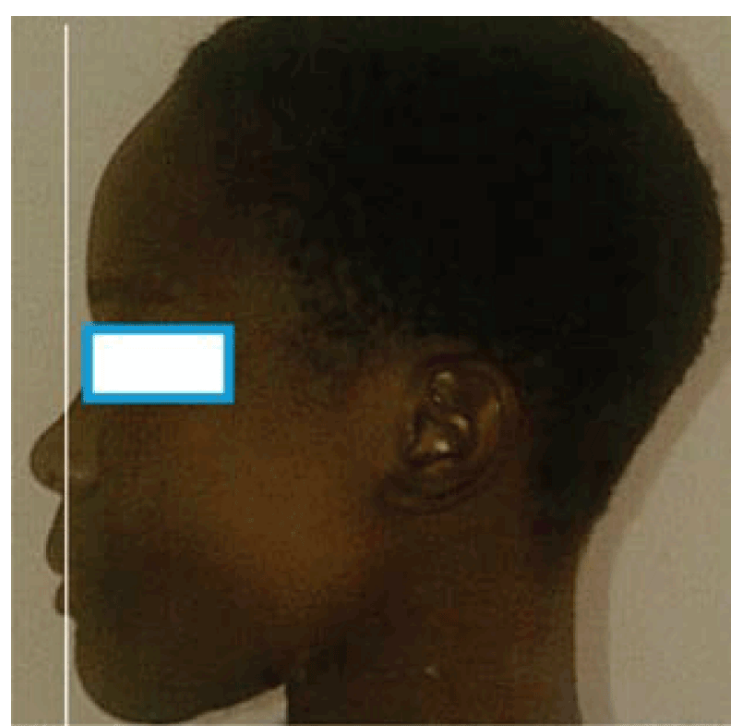

Figure 3: Showing side view of post-operative photograph of the patient

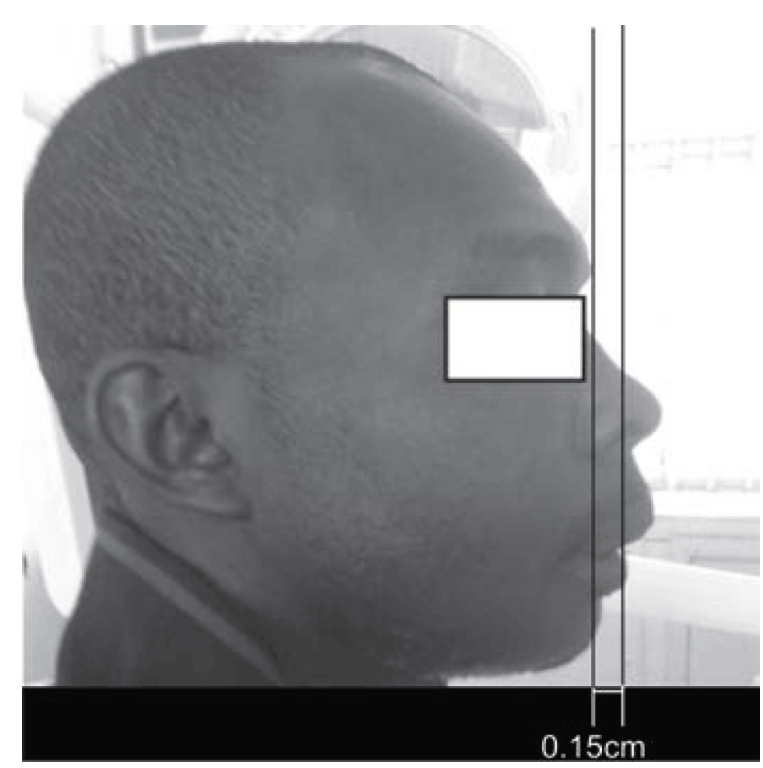

Figure 4: Showing side view of post-operative photograph of the fourth male patient

\section{Results}

For chin position, for the first male patient, 9 (81.2\%) clinicians including both consultants graded the chin to be mildly retruded while $4(36.4 \%)$ para-clinicians graded as mildly retruded. For the second patient, 7 (63.6\%) clinicians graded the chin mildly retruded including the consultant restorative dentist, while 2 (18.2\%) felt it was normal. For the first female patient (serial no. 6), more assessors in both groups considered the chin to be mildly protruded but more clinicians, $5(45.5 \%)$ perceived to be normal. Only 1 (9.1\%) in each group assessed the chin of the second patient to be in normal position. Assessments of other patients are also reflected in Table 1.

$\mathrm{F}$ values for moderate, mild retrusion, normal, mild and moderate protrusion were $0.387,5.089,7.800,12.500$ and 9.800 with $P$ values of $0.542,0.037,0.012,0.002$ and 0.006 respectively. From the objective analysis, $5(50 \%)$ of the patients had their chin in normal or very close to normal positions and $4(40 \%)$ had mild retrusions $(\leq 2 \mathrm{~mm})$ and 1 (10\%) had moderate retrusion $(\geq 2 \mathrm{~mm})$. When subjective and objective evaluations were compared, more clinicians graded more accurately than para-clinicians in all the patients.

For symmetry, most of the assessors graded mild symmetry in the first male patient; 6 (54.5\%) assessors in each group graded symmetry in the second patient. Assessments of the other patients are also reflected in Table 2.

F values for symmetry, mild and moderate asymmetry were 0.280 , 0.063 and 0.316 with $\mathrm{P}$ values of $0.603,0.805$, and 0.581 respectively. Four (40\%), ( 1 male and 3 female) patients graded themselves mild asymmetries. None of the assessors and patients graded position or symmetry to be severe.

Following objective assessments, $8(80 \%)$ patients had less than 2 $\mathrm{mm}$ (mild), 1 (10\%) patient had $2.5 \mathrm{~mm}$ (moderate $\geq 2$ and $\leq 4 \mathrm{~mm}$ ) and $1(10 \%)$ had $5.5 \mathrm{~mm}$ (severe). Five or more assessors in both groups graded correctly in 6 patients.

For protrusion/retrusion, there was no significant difference between the subjective assessments of the clinicians and $2 \mathrm{D}$ photo analysis, $\mathrm{p}>0.05 ; 0.98$. Also, there was no significant difference between the subjective assessments of the para-clinicians and 2D photo analysis $p>0.05 ; 0.07$. However value was much higher for the clinical group. $\mathrm{P}$ values for the symmetry variable were 0.16 and 0.31 respectively.

\section{Discussion}

Only few articles in the maxillofacial literature have made contributions in this specific area of research on evaluating the reconstructed chin [5,6]. In our study, majority of the assessments fell within mild retrusion, normal and mild protrusion but opinions were more divided amongst para-clinicians, this was comparable to some of the findings of Cochrane et al. [6].

All the patients/parent considered the chin positions to be normal, probably because they were satisfied with their postoperative facial profile when compared with the preoperative status. Photo analyses also showed that majority of the cases were normal or mildly retruded. Majority of the assessments fell with mild and moderate asymmetries and more of the moderate asymmetries were observed amongst the male patients by both groups. Four (40\%) patients perceived their chin to be mildly asymmetric. In our third male patient, earlier surgery by non specialists contributed to recurrence, deviation and asymmetry of the mandible, but this was slightly corrected with intermaxillary fixation (IMF) following plate reconstruction. 
Citation: Akinbami BO, Udeabor SE (2014) Assessment of Position and Symmetry of the Chin Following Reconstruction of Mandible with Autogenous lliac Bone Grafts and Non Pre-Shaped Titanium Reconstruction Plates: A Comparative Pilot Study of Visual Perception and Computer Analyzed 2D Photo Image. Dentistry 4: 264. doi:10.4172/2161-1122.1000264

Page 4 of 5

\begin{tabular}{|c|c|c|c|c|c|c|c|c|c|c|c|c|}
\hline \multirow{2}{*}{$\begin{array}{l}\text { Serial } \\
\text { no. }\end{array}$} & \multicolumn{5}{|l|}{ Clinicians } & \multicolumn{5}{|c|}{ Para-clinicians } & \multirow[t]{2}{*}{ Patient } & \multirow[t]{2}{*}{$2 D$ image } \\
\hline & $\begin{array}{l}\text { Moderate } \\
\text { retrusion }\end{array}$ & $\begin{array}{l}\text { Mild } \\
\text { retrusion }\end{array}$ & Normal & $\begin{array}{l}\text { Mild } \\
\text { protrusion }\end{array}$ & $\begin{array}{l}\text { Moderate } \\
\text { protrusion }\end{array}$ & $\begin{array}{l}\text { Moderate } \\
\text { retrusion }\end{array}$ & $\begin{array}{l}\text { Mild } \\
\text { retrusion }\end{array}$ & Normal & $\begin{array}{l}\text { Mild } \\
\text { protrusion }\end{array}$ & $\begin{array}{l}\text { Moderate } \\
\text { protrusion }\end{array}$ & & \\
\hline 1 & $1(9.1)$ & $9(81.8)$ & $1(9.1)$ & $0(0)$ & $0(0)$ & $1(9.1)$ & $4(36.4)$ & $0(0)$ & $5(45.5)$ & $1(9.1)$ & Normal & $\begin{array}{l}1.2 \\
\mathrm{~mm}(\mathrm{MR})\end{array}$ \\
\hline 2 & $2(18.2)$ & $7(63.6)$ & $2(18.2)$ & $0(0)$ & $0(0)$ & $0(0)$ & $3(27.3)$ & $2(18.2)$ & $4(36.4)$ & $2(18.2)$ & Normal & $\begin{array}{l}2.5 \\
\mathrm{~mm}(\mathrm{MoR})\end{array}$ \\
\hline 3 & $0(0)$ & $4(36.4)$ & $3(27.3)$ & $4(36.4)$ & $0(0)$ & $0(0)$ & $1(9.1)$ & $1(9.1)$ & $5(45.5)$ & $4(36.4)$ & Normal & $0 \mathrm{~mm}(\mathrm{~N})$ \\
\hline 4 & $2(18.2)$ & $5(45.5)$ & $4(36.4)$ & $0(0)$ & $0(0)$ & $5(45.5)$ & $1(9.1)$ & $1(9.1)$ & $3(27.3)$ & $1(9.1)$ & Normal & $\begin{array}{l}1.5 \\
\mathrm{~mm}(\mathrm{MR})\end{array}$ \\
\hline 5 & $0(0)$ & $4(36.4)$ & $6(54.5)$ & $0(0)$ & $1(9.1)$ & $2(18.2)$ & $4(36.4)$ & $3(27.3)$ & $1(9.1)$ & $1(9.1)$ & Normal & $\begin{array}{l}1.6 \\
\mathrm{~mm}(\mathrm{MR})\end{array}$ \\
\hline 6 & $0(0)$ & $0(0)$ & $5(45.5)$ & $4(36.4)$ & $2(18.2)$ & $0(0)$ & $0(0)$ & 1(9.1) & $7(63.6)$ & $3(27.3)$ & Normal & $0 \mathrm{~mm}(\mathrm{~N})$ \\
\hline 7 & $3(27.3)$ & $5(45.5)$ & $1(9.1)$ & $2(18.2)$ & $0(0)$ & $3(27.3)$ & $4(36.4)$ & $1(9.1)$ & $1(9.1)$ & $2(18.2)$ & Normal & $\begin{array}{l}1.0 \\
\mathrm{~mm}(\mathrm{MR})\end{array}$ \\
\hline 8 & $0(0)$ & $1(9.1)$ & $9(81.8)$ & $1(9.1)$ & $0(0)$ & $0(0)$ & $0(0)$ & $5(45.5)$ & $6(54.5)$ & $0(0)$ & Normal & $0 \mathrm{~mm}(\mathrm{~N})$ \\
\hline 9 & $0(0)$ & $3(27.3)$ & $6(54.5)$ & $2(18.2)$ & $0(0)$ & $0(0)$ & $1(9.1)$ & $2(18.2)$ & $7(63.6)$ & $1(9.2)$ & Normal & $0 \mathrm{~mm}(\mathrm{~N})$ \\
\hline 10 & $0(0)$ & $4(36.4)$ & $5(45.5)$ & $1(9.1)$ & $1(9.1)$ & $1(9.2)$ & $2(18.4)$ & $0(0)$ & $5(45.5)$ & $3(27.3)$ & Normal & $\begin{array}{l}0.2 \\
\mathrm{~mm}(\mathrm{CN})\end{array}$ \\
\hline
\end{tabular}

Table 1: Subjective and objective Evaluations for Position of the Chin in 10 Patients with Mandibular Reconstruction

\begin{tabular}{|c|c|c|c|c|c|c|c|c|}
\hline \multirow{2}{*}{$\begin{array}{l}\text { Serial } \\
\text { no. }\end{array}$} & \multicolumn{3}{|l|}{ Cinicians } & \multicolumn{3}{|c|}{ Para-clinicians } & \multirow[t]{2}{*}{ Patient } & \multirow{2}{*}{$\begin{array}{l}\text { 2D Image } \\
\begin{array}{l}\text { Difference in } \\
\text { chin width }\end{array}\end{array}$} \\
\hline & Symmetry & Mild Asymmetry & $\begin{array}{l}\text { Moderate } \\
\text { Asymmetry }\end{array}$ & Symmetry & Mild Asymmetry & $\begin{array}{l}\text { Moderate } \\
\text { Asymmetry }\end{array}$ & & \\
\hline 1. & $3(27.3)$ & $7(63.6)$ & $1(9.1)$ & $2(18.2)$ & $8(72.7)$ & $1(9.1)$ & Normal & $0.7 \mathrm{~mm}$ \\
\hline 2. & $6(54.5)$ & $2(18.2)$ & $3(27.3)$ & $6(54.5)$ & $4(36.4)$ & $1(9.1)$ & Normal & $0.5 \mathrm{~mm}$ \\
\hline 3. & $0(0)$ & $2(18.2)$ & $9(81.8)$ & $0(0)$ & $0(0)$ & $11(100)$ & Mild asymmetry & $1.5 \mathrm{~mm}$ \\
\hline 4. & $0(0)$ & $5(45.5)$ & $6(54.5)$ & $0(0)$ & $6(54.5)$ & $5(45.5)$ & Normal & $0.2 \mathrm{~mm}$ \\
\hline 5. & $0(0)$ & $9(81.8)$ & $2(18.2)$ & $0(0)$ & $5(45.5)$ & $6(54.5)$ & Normal & $0.8 \mathrm{~mm}$ \\
\hline 6 & $4(36.4)$ & $7(63.6)$ & $0(0)$ & $2(18.2)$ & $9(81.8)$ & $0(0)$ & Normal & $1.5 \mathrm{~mm}$ \\
\hline 7. & $0(0)$ & $8(72.7)$ & $3(27.3)$ & $1(9.1)$ & $6(54.5)$ & $4(36.4)$ & Mild asymmetry & $1.0 \mathrm{~mm}$ \\
\hline 8. & $0(0)$ & $10(90.9)$ & $1(9.1)$ & $2(18.2)$ & $7(63.6)$ & $2(18.2)$ & Mild asymmetry & $5.5 \mathrm{~mm}$ \\
\hline 9. & $5(45.5)$ & $6(54.5)$ & $0(0)$ & $2(18.2)$ & $9(81.8)$ & $0(0)$ & Normal & $1.0 \mathrm{~mm}$ \\
\hline 10 & $2(18.2)$ & $6((54.5)$ & $3(27.3)$ & $0(0)$ & $5(45.5)$ & $6(54.5)$ & Mild asymmetry & $2.5 \mathrm{~mm}$ \\
\hline
\end{tabular}

Table 2: Subjective and objective Evaluations for Symmetry of the Chin in 10 Patients with Mandibular Reconstruction

IMF with eyelets on residual teeth or Fix Bridge appliance is necessary before adapting the plates. Also, reconstruction plates should normally be preshaped by 3DCT mirror imaging of the intact side of the jaw and stereolithographic models $[7,8]$, but this is difficult to achieve with gross destruction of mandible of both sides by locally aggressive tumors. For these reasons we had to shape the plates after resection of the jaw in the theatre. In 3 of the patients, the whole tooth bearing portion of the jaw was resected, IMF could not be achieved to relate the lower jaw to the maxilla before adaptation. A flat caliper in parallel contact with the labial surfaces of the upper central incisors and the anterior surface of the reconstruction plate was a useful technique to ensure chin position; and symmetry was improved on by 
Citation: Akinbami BO, Udeabor SE (2014) Assessment of Position and Symmetry of the Chin Following Reconstruction of Mandible with Autogenous lliac Bone Grafts and Non Pre-Shaped Titanium Reconstruction Plates: A Comparative Pilot Study of Visual Perception and Computer Analyzed 2D Photo Image. Dentistry 4: 264. doi:10.4172/2161-1122.1000264

Page 5 of 5

relating the anterior bends of the plates to the midline and upper canines when present. The asymmetries in some of our patients were not so severe and, none of them requested second operation to correct the position of the mildly retruded, protruded or asymmetric chin.

Achieving normal position during operation is also difficult due to disparity in intervals between the holes in the plates and normal interdental spaces. The position of the plate that appeared normal during operation with patient's head in supine position may come out not exactly as it was after the operation. With adequate preoperative assessment and intra-operative measurements, the discrepancies were usually acceptable $[9,10]$. There was usually a thin line in the differentiation and appreciation of mildly retruded, normal and mildly protruded position, that is, some difficulties exists in the differentiation of these three closely related positions by some of the individual assessors especially in the para-clinician group. However, appreciation of normal position of chin after operation is also closely influenced by the size of the tumor, extent of soft tissue infiltration, amount of tissue sacrificed, premorbid form of the mandible and probably the position of the assessor's chin [10-16]. Some patients were more satisfied with a mildly retruded position rather than a protruded position. One limitation of this study was the unavailability of cephalometry machine which would have contributed to the quantitative analysis of position and symmetry of the plates. However, our study has highlighted that, in order to improve post-operative facial profile, it must be ensured that the anterior surface of the plate extends to an imaginary vertical line from the labial surface of the upper incisors and the positions of curvatures of the plates must be related to the upper canines.

In conclusion, there was more discrepancy in the judgments' of the assessors between the two groups than within groups possibly because of the differences in the levels of training, as well as perception and understanding of the facial profile. Based on objective evaluation, the chin positions were normal or very close to normal in half of the cases, while symmetry was very close to normal in only one case.

\section{References}

1. Goh BT, Lee S, Tideman H, Stoelinga PJ (2008) Mandibular reconstruction in adults: a review. Int J Oral Maxillofac Surg 37: 597-605.

2. Zwetyenga N (2009) [Overview and perspective of mandibular reconstruction]. Rev Stomatol Chir Maxillofac 110: 185-187.
3. Delacure M (2007) Reconstruction of the mandible. Indian J Plast Surg 40: 28.

4. Sajid MA, Warraich RA, Abid H, Ehsan-ul-Haq M, Shah KL, et al. (2011) Reconstruction of mandibular defects with autogenous bone grafts: a review of 30 cases. J Ayub Med Coll Abbottabad 23: 82-85.

5. Naini FB, Donaldson ANA, McDonald F, Cobourne MT (2012) Assessing the influence of chin prominence on perceived attractiveness in the orthognatic patic, clinician and layperson. Int J Oral Maxillofac Surg 41: 839.

6. Cochrane SM, Cunningham SJ, Hunt NP (1999) A comparison of the perception of facial profile by the general public and 3 groups of clinicians. Int J Adult Orthodon Orthognath Surg 14: 291-295.

7. Poli T, Ferrari S, Bianchi B, Sesenna E (2003) Primary oromandibular reconstruction using free flaps and thorp plates in cancer patients: a 5year experience. Head Neck 25: 15-23.

8. Chiapasco M, Colletti G, Romeo E, Zaniboni M, Brusati R (2008) Longterm results of mandibular reconstruction with autogenous bone grafts and oral implants after tumor resection. Clin Oral Implants Res 19: 1074-1080.

9. Jewer DD, Boyd JB, Manktelow RT, Zuker RM, Rosen IB, et al. (1989) Orofacial and mandibular reconstruction with the iliac crest free flap: a review of 60 cases and a new method of classification. Plast Reconstr Surg 84: 391-403.

10. Costantino PD, Johnson CS, Friedman CD, Sisson GA Sr (1995) Bone regeneration within a human segmental mandible defect: a preliminary report. Am J Otolaryngol 16: 56-65.

11. Urken ML, Weinberg H, Vickery C, Buchbinder D, Lawson W, Biller HF (1991) Oromandibular reconstruction using microvascular composite free flaps. Arch Otolaryngol Head Neck Surg 117:733.

12. Burkey BB, Coleman JR Jr (1997) Current concepts in oromandibular reconstruction. Otolaryngol Clin North Am 30: 607-630.

13. Hidalgo DA, Pusic AL (2002) Free-flap mandibular reconstruction: a 10year follow-up study. Plast Reconstr Surg 110: 438-449.

14. Szpindor E (1995) [Evaluation of the usefulness of autogenic bone grafts in reconstruction of the mandible]. Ann Acad Med Stetin 41: 155-169.

15. Myoung H, Kim YY, Heo MS, Lee SS, Choi SC, et al. (2001) Comparative radiologic study of bone density and cortical thickness of donor bone used in mandibular reconstruction. Oral Surg Oral Med Oral Pathol Oral Radiol Endod 92: 23-29.

16. Disa JJ, Hidalgo DA, Cordeiro PG, Winters RM, Thaler H (1999) Evaluation of bone height in osseous free flap mandible reconstruction: an indirect measure of bone mass. Plast Reconstr Surg 103: 1371-1377. 